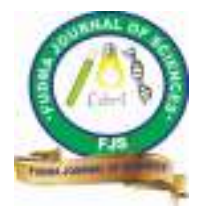

FUDMA Journal of Sciences (FJS)

ISSN online: $2616-1370$

ISSN print: 2645 - 2944

Vol. 4 No. 3, September, 2020, pp $505-512$

DOI: https://doi.org/10.33003/fjs-2020-0403-368

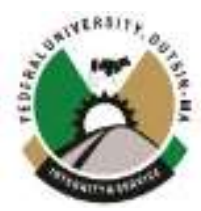

\title{
EFFECTS OF LANDUSE AND LANDCOVER CHANGE ON FLOODING IN KANO METROPOLIS, KANO STATE, NIGERIA
}

\author{
${ }^{1}$ I. Mukhtar, ${ }^{1}$ E. O. Iguisi, ${ }^{2}$ A. U. Shehu, ${ }^{1}$ Y. Dabo, ${ }^{3}$ M. Abubakar, ${ }^{1}$ S. M. Zubairu, and ${ }^{1}$ A. Balarabe \\ ${ }^{1}$ Department of Geography and Environmental Management, Ahmadu Bello University, Zaria, Kaduna State, Nigeria \\ ${ }^{2}$ Department of Environmental Sciences, Federal University Dutse, Jigawa State, Nigeria \\ ${ }^{3}$ Division of Agricultural Colleges, Ahmadu Bello University, Zaria, Kaduna Sate, Nigeria
}

Corresponding Author's email: mukheee2002@gmail.com

\begin{abstract}
This paper looked at the change in land use land cover (LULC) of Kano metropolis from 2001 to 2012; projected to 2035 and thereby assessing the response of these different land covers to rainfall event using the Hydrologic Engineering Corps- Hydrologic Modelling System (HEC-HMS) model. The outcome of the LULC revealed that the built-up areas increased from $19.7 \%$ to $34.4 \%$ and then to $54.4 \%$ in 2001,2012 and 2035, respectively. The discharge of Jakara basin indicated a rise from 2001, 2012 to 2035 in the order of $443,585.2$ to $609.7 \mathrm{~cm}^{3} / \mathrm{sec}$ respectively. However, that of Chalawa shows increase between 2001 and 2012 and a decrease in 2035 as a result of canalization within the basin. The paper recommended adherence to the city masterplan and construction of canals within each sub-drainage basin for proper conveyance of run-off discharge.
\end{abstract}

Keywords: Landuse and Landcover (LULC), HEC-HMS model, Chalawa basin, Jakara basin and sub- drainage basins.

\section{INTRODUCTION}

Urbanization aggravates run-off by restricting where flood waters can go. In an urban area, large parts of the ground are covered with roofs, tarred roads and pavements. These obstruct sections of natural channels, infiltration and built drains that ensure water movement to rivers faster than it could under the natural conditions. Another factor in an urban setting is the population density. As more people crowd into cities like Kano Metropolis, so does the floods effect intensify because of the tendency to create more impervious surfaces. Consequently even quite moderate storms could produce high flows within a drainage basin because there are more hard surfaces than drains (Action Aid International, 2006). In extreme cases urban floods can result in disasters that setback urban development by years or even decades. Given the high spatial concentration of people and values in cities, even small scale floods may lead to considerable damages. Statistics clearly indicate that economic damages caused by urban floods are rising (MunichRe, 2005).

It is displeasing to note that, urban areas in Nigeria are particularly vulnerable to flooding due to inadequate drainage system; changes in ecosystem through the replacement of natural and absorptive soil cover with concrete; and deforestation of hillsides, which has the effect of increasing the quantity and rate of runoff. In the developed countries, flood forecasting and prediction, flood control and mitigation, early warning systems, disaster response and management have been in the forefront, however in most developing countries (including Nigeria), these responses are mostly inadequate. Flood early warning, prediction, and mitigation would have

\section{MATERIALS AND METHODS}

\section{Study Area}

Kano Metropolis is located within latitudes $11^{0} 52$ ' $30^{\prime \prime} \mathrm{N}$ to $12^{0} 7{ }^{\prime} 30^{\prime} \mathrm{N}$ and Longitudes $8^{0} 25^{\prime} 30^{\prime \prime} \mathrm{E}$ to $8^{0} 40^{\prime}$ E. The boundary of the Metropolis keeps changing with time (Mortimore, 1989) as a result of urban sprawl. The Metropolis is made up of eight Local Government Areas namely: Municipal, Gwale, Dala, Fagge, Tarauni, Nassarawa, Kumbotso, and Ungoggo (Fig.1). The study rather been better programmes than search and rescue, relief and rehabilitation programmes found in developing countries (Jeb, 2013).

Assessing flood hazard and related vulnerabilities often require knowledge of land use and land cover, run-off rate as well as human and environmental attributes of the communities. Land use and land cover (LULC) models such as the Markov model is a class of probability model used to study the evolution of a system over time. Transition probabilities are used to identify how a system evolves from one time period to the next. A Markov chain is the behavior of the system over time, as described by the transition probabilities and the probability of the system being in various states (www.jatit.org, 2017).

Hydrological models are regarded as powerful tools for predicting drainage basin response to rainfall events and assessment of impacts of parameters such as land-use and cover change on drainage basin hydrology (Whitehead and Robinson, 1993). The complexities of global flood disasters need a much technical approach than the conventional methods used, this will lead to a more effective management, reduction and forecasting of flood events. Alghmand, Abdullah, Abustan and Vosoogh (2010) reiterated that information on drainage basin characteristics and response to rainfall help reduce risk and vulnerability levels within the basins and mitigate future occurrence of flood events. 
area comprises of two drainage basins: the Challawa river basin in the south with an area of $109.8 \mathrm{~km}^{2}, 17$ sub-basins, 8 junctions and Jakara river basin in the north with an area of $104.9 \mathrm{~km}^{2}, 15$ sub-basins and 7 junctions (Fig.2).

\section{Land use Classification}

The first step was to download the satellite image, and then the image was georeferenced to the coordinate system of the study area from World Geodic System 1984 Projection to Universal Transverse Mercator (WGS84 to UTM, Zone 32N). Visual image by colour compositing of three band 3,2, and 1 for red, green and blue respectively.

The next step is to define spectral characteristics of different classes by identifying sample areas. Samples of a specific class include a number of training pixels into groups (classes) according to their spectral characteristics to see how it relates to the sample classes.

After defining the training sample, the method of maximum likelihood classification was applied in order to obtain the land use land cover classification.

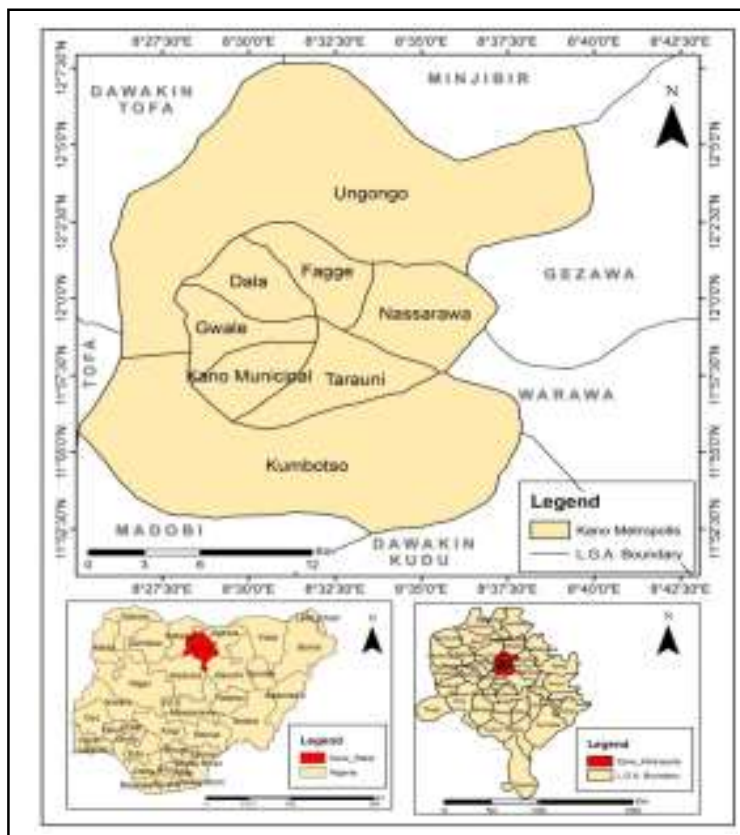

Figure 1: Map of the Study Area

Source:Adapted from the Administrative map of Kano State

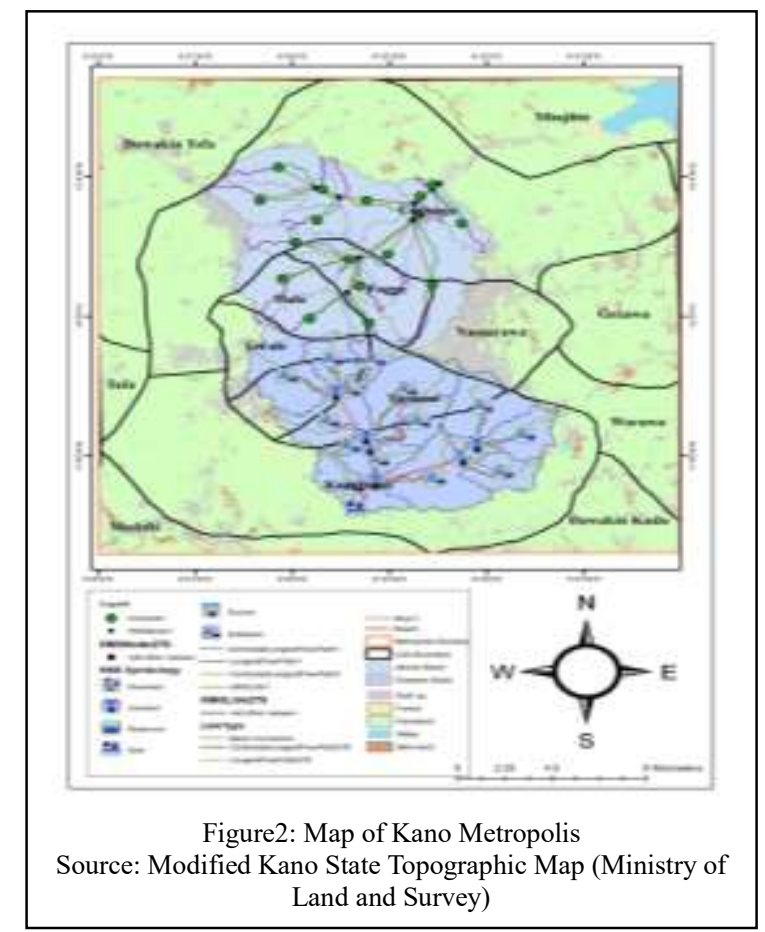

package.DEM was used to access several potential catchments within the study area. The catchment for the study area was chosen for further investigation and processing. The extracted DEM for the catchment was further examined to visualize the drainage system and was compared with existing stream network on existing topo maps of the study area.

Figure 3 shows the steps involved in terrain processing using HEC-Geo HMS and ArcHydro in ArcGIS software. 


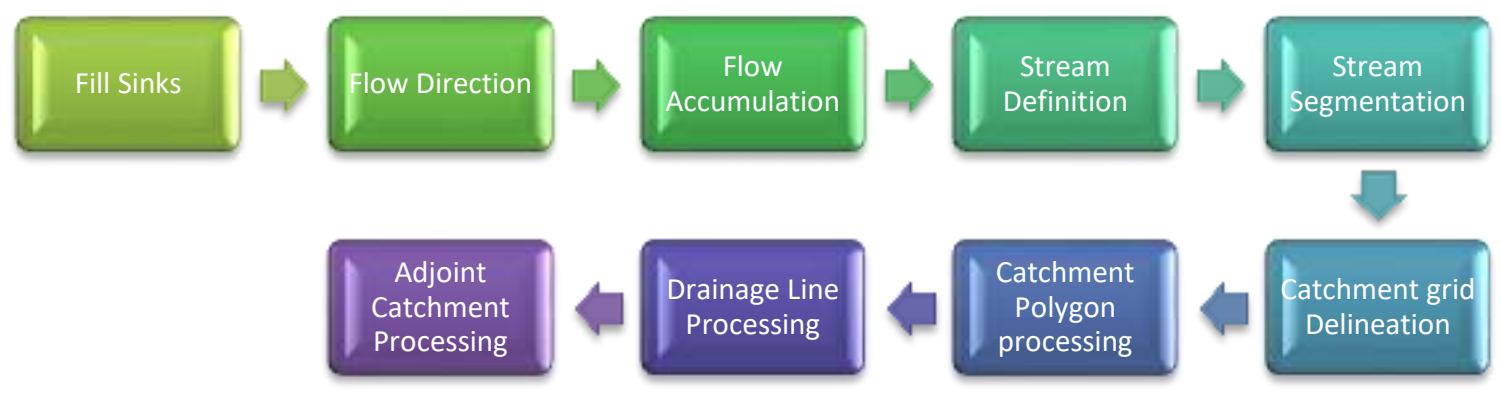

Figure 3: Physiographic Data Extraction Using HEC-Geo HMS and ArcHydro Source: Fieldwork, 2016

\section{RESULTS AND DISCUSSIONS \\ Nature of Land Use and Land Cover Change in Kano Metropolis}

The study area was categorized into five (5) thematic classes under supervised classification which are; built-up areas, Forest, farmland, water and bare land. The analysis was carried out for 2001, 2012 and 2035. The Jakara Basin occupies the northern part of the metropolis comprising of 17 sub-basins within Gwale, Dala, Fagge, Ungoggo and Nassarawa while the Chalawa basins occupy the southern part of the metropolis comprising of 15 sub-basins within Kumbotso, Tarauni, Kano Municipal part of Gwale, Dala and Fagge, the entire study area covers an area of $767.23 \mathrm{~km}^{2}$.

\section{Kano Metropolis 2001 Land Use and Land Cover}

In 2001 over $60 \%$ of the metropolis was occupied by farmland and $19.7 \%$ by built-up areas. The sub-basins that made up most part of the built-up areas are W310, W280, W330 and W250 in Jakara basin and W170, W180, W210 and W200 in the Chalawa basin. This is believed to influence the peak discharge of the basins (see figures 4, 5 and 6 ), but as a result of the high percentage of open pervious surfaces, there is a possibility of high infiltration which results in low run- off. This depicts the findings of Balaid (2003) Ismail et.al. (2010), where it was observed that open spaces, forests, and farmlands increased the amount of infiltration or delayed time of peak discharge.

\section{Kano metropolis 2012 land Use Land Cover Change}

The LULC in 2012 shows a different trend with the pervious surfaces (farmland, forest, bare land and water bodies) constituting less than $66 \%$ of the entire metropolis. The builtup areas increased from $150.9 \mathrm{~km}^{2}$ in 2001 to $263.4 \mathrm{~km}^{2}$ in 2012 almost a $50 \%$ increase. This signifies the increase in impervious surface and hence increased in runoff. These findings are in tune with the results of Ejao and Abdullahi (2013) and Mishraet.al (2012) where changes are skewed towards built-up areas as a result of rapid urban development. Figure 4, 5 and 6 indicates that sub-basins W160, W170, W180, W190 and W230 have had over $20 \%$ increase in built up areas in the Chalawa basin, while the Jakara basin had a $30 \%$ increase in built up areas in sub-basins W340, W330, W310, W280, and W270, which indicates a possible increase in run-off accumulation.

\section{Kano Metropolis 2035 Land use Land Cover Change Projection}

The percentage of built-up areas in 2035 jumps to over $50 \%$ (Figure 4, 5 and 6) of the entire metropolis leaving the pervious surfaces with less than $45 \%$. This sharp rise in impervious surfaces leads to increase in runoff. Balogun et.al (2011), Mashere and Malthus (2013) reported similar findings and attributed it to a rise in flash flood incidences in their study areas. Kano metropolis have experienced a drastic change in land use and land cover mostly from pervious to impervious surfaces which could be attributed to the rise in flood incidences as a result of run-off accumulation. Studies by Ishaya et.al (2009), Ogba et al.,(2009) and Cummings et.al (2012) further reiterated the influence of rapid urbanization on flood occurrences.

\section{Run- Off Discharge of Jakara Drainage Basin}

The Jakara basin has an area of $109.7 \mathrm{~km}^{2}$ and 17 sub-basins. The results presented below are simulations for rainfall events of 2001, 2012 and 2035 that resulted in massive flooding. The rainfall event of 2001 that occurred on the $25^{\text {th }}$ of August had a total volume of $163 \mathrm{~mm}^{3}$ while that of 2012 had a volume of $143 \mathrm{~mm}^{3}$ on the $7^{\text {th }}$ of August which was also replicated for 2035 forecast. 
Jakara Run off Discharge Simulation 2001

Sub -basins W310 has an area of $13.35200 \mathrm{~km}^{2}$ and a peak discharge of $70.2 \mathrm{~cm}^{3} / \mathrm{sec}$. the total depth of run-off is $0.65 \mathrm{~mm}^{3}$, a total loss of $0.25 \mathrm{~mm}^{3}$ at the beginning of the storm event and reached field capacity within 3 hrs 30 mins. The basin covers a large part of Dala Local Government Area which is known to be a highly urbanized area with most part of it impervious.
Sub-basin W280 covers part of Nasarawa, Fagge and drains into Ungoggo LGA. It covers an area of $20.274 \mathrm{~km}^{2}$ and a peak discharge of $114.2 \mathrm{~cm}^{3} / \mathrm{sec}$. The basin had a flow depth of $0.6 \mathrm{~mm}^{3}$ and a loss $0.2 \mathrm{~mm}^{3}$ over a period of $4 \mathrm{hrs}$ before reaching field capacity. This basin is also highly urbanized and large, thus the reason for the high flow rate.
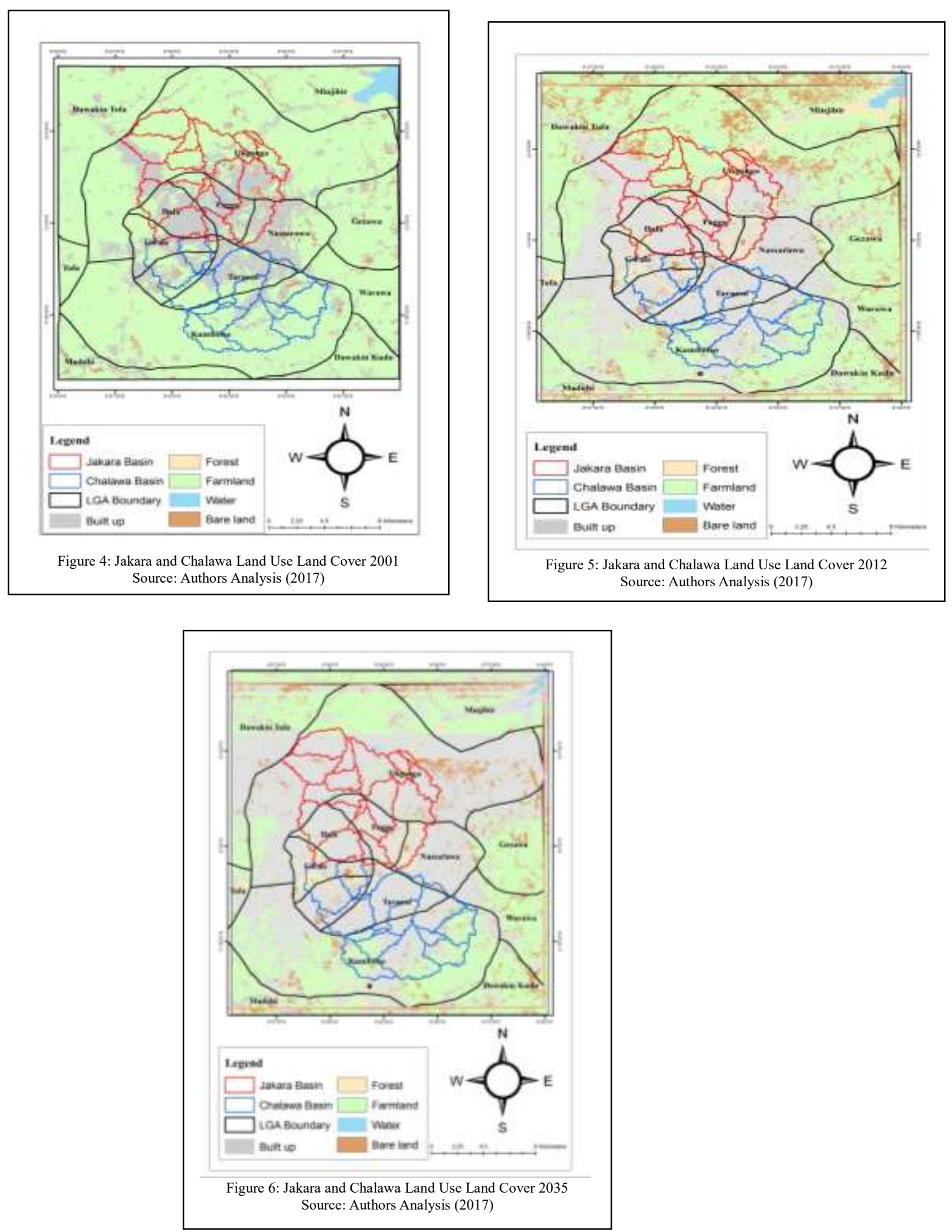
Sub-basins W190 and W300 are the smallest in size with 0.70592 and $0.68870 \mathrm{~km}^{2}$ respectively. Even though W190 is slightly larger than W300 the peak discharge is less due to higher impervious surfaces. W300 had a peak discharge of $3.6 \mathrm{~cm}^{3} / \mathrm{sec}$ whileW190 has $3.4 \mathrm{~cm}^{3} / \mathrm{sec}$ with a loss of $0.4 \mathrm{~mm}^{3}$ and $0.62 \mathrm{~mm}^{3}$ over $6 \mathrm{hrs}$ respectively. This indicates less inundation for W190 as a result of being within the Ungoggo axis with more pervious surface and high discharge for W300 which is situated within Fagge area and highly developed. The Outlet of the entire basin has a peak discharge of $446.2 \mathrm{~cm}^{3} / \mathrm{sec}$ (Figure 7). The findings is in agreement with that of Ishman (2014) that increased development of impervious layers increases flow discharge of a basin.

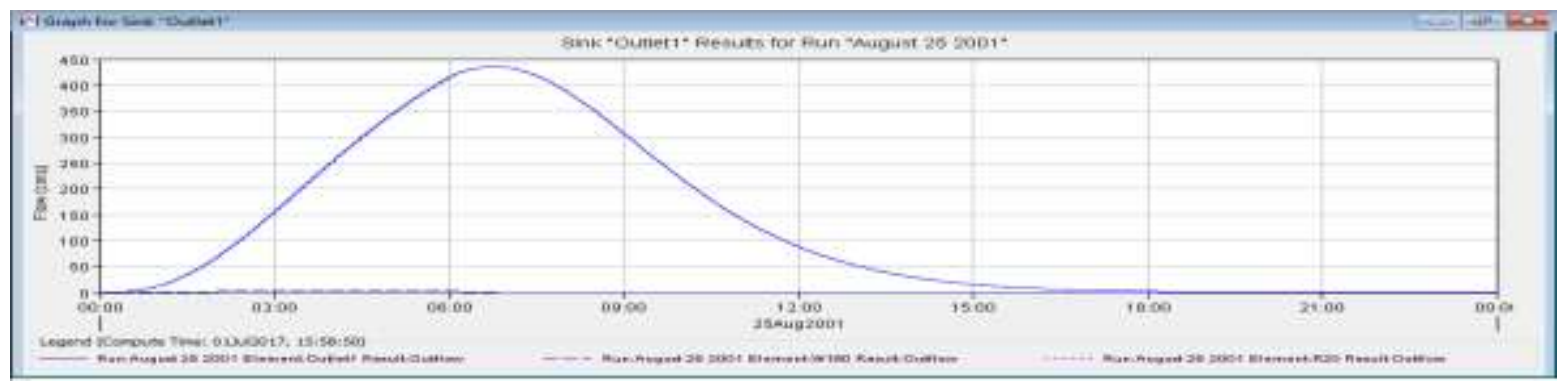

Figure 7: Jakara BasinTotal Run-Off 2001

Jakara Run off Discharge Simulation 2012

The trend of peak discharge of the various sub-basins resembles that of 2001 but with an increase in the number of sub-basins with higher peak discharge of above $55 \mathrm{~cm}^{3} / \mathrm{sec}$. The highest was also observed in W280 with $137.2 \mathrm{~cm}^{3} / \mathrm{sec}$., this is as result of an increase in impervious layers in the sub-basins that had lower peak discharge in 2001. Sub-basins W310, W250, and W330 had peaks of $84.2,61.0$ and $59.8 \mathrm{~cm}^{3} / \mathrm{sec}$ which is quite higher than that of 2001 both in quantity and number of basins with such discharges, the outlet's peak discharge is $585.2 \mathrm{~cm}^{3} / \mathrm{sec}$,(Figure 8 ) this shows an increase in discharge of $130 \mathrm{~cm} 3 / \mathrm{sec}$ although with a lower observed rainfall intensity. W300 and W190 had peaks of 4.7 and $4.2 \mathrm{~cm}^{3} / \mathrm{sec}$ which shows a slight increase in volume compared to 2001. The outcome coincides with that of Screenivasulu and Bhaskar (2010) where the study noticed a sharp increase in discharge of developed small basins and high incidences of flash floods.

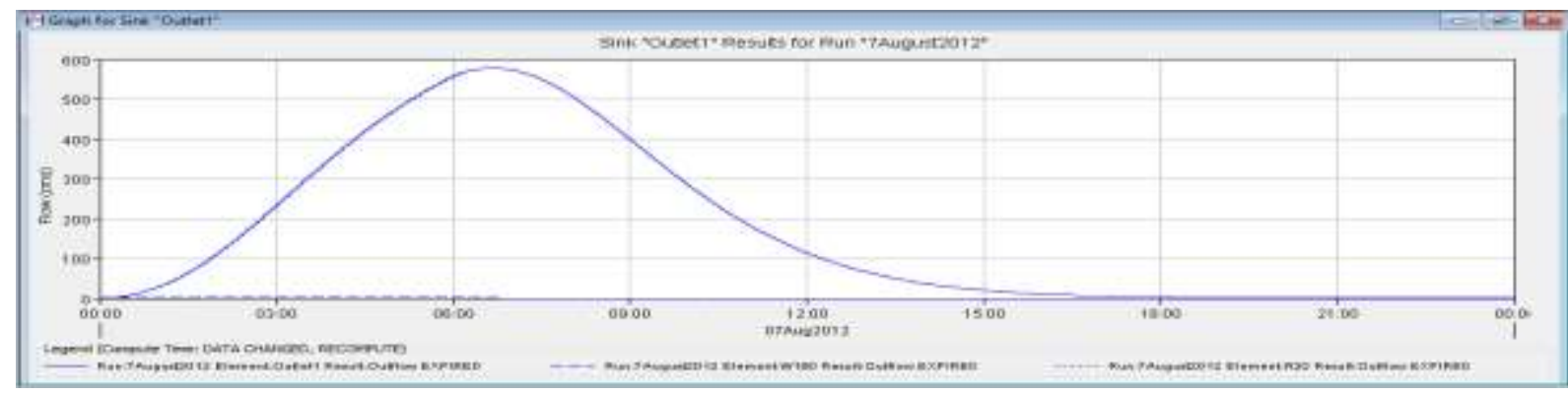

Figure 8: Jakara Total Run-Off 2012

Jakara Run off Discharge Simulation 2035 Forecast

In 2035, using the same rainfall amount of 2012 but projected land use and land cover values, gave a slight rise in peak discharge for few sub-basins especially the less urbanized areas in 2012. There was an increase in peak discharge in sub-basins W310, W340, W180, the outlet W190, W250 and W210 with $88.3,30.7,56.4,609.7$, and $4.7 \mathrm{~cm}^{3} / \mathrm{sec}$. (see Figure 9), likewise the loss was also low, (see Figure 4.) these reflects the influence of increased imperviousness of the surface. This was also observed in the study of Samarasingh et.al. (2010), Alghamand et.al. (2010) and Garcia-Pintado (2013), where an increase in impervious surfaces raised the amount of run-off, reduced the time of peak discharge and increased the extent and velocity of flood waters. As revealed, flooding will increase in extent and depth within sub-basins that were not affected in 2012 due to an increase in the extent of built up areas (see Figure 4, 5 and 6). 


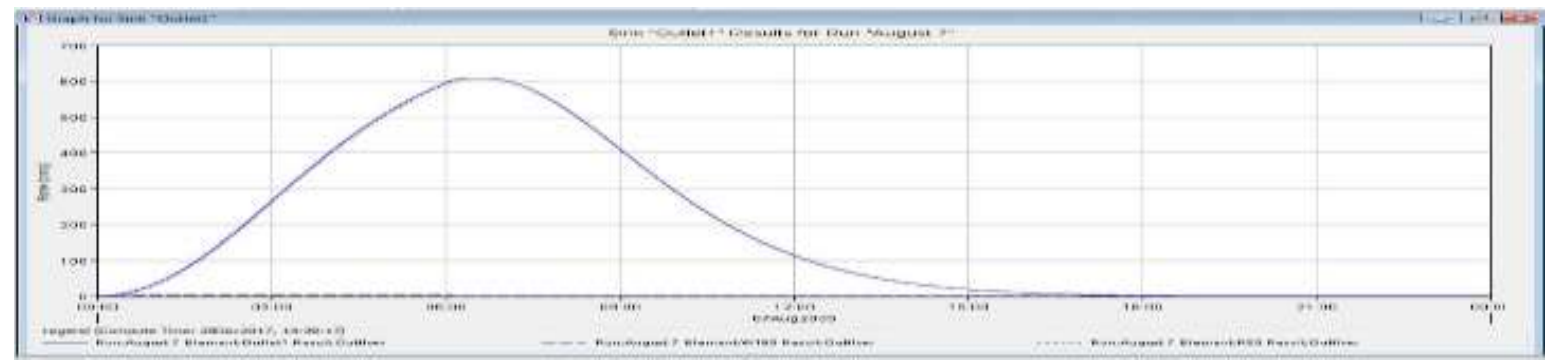

Figure 9:Jakara Total Run-Off 2035 projection

Chalawa Run off Discharge Simulation 2001

This presents the result and discussion of the amount of runoff in Chalawa drainage basin of 2001, 2012 and 2035. The basin has an area of $104.9 \mathrm{~km}^{2}$ and $15 \mathrm{sub}$-basins, the rainfall event of
2001 that occurred on the $25^{\text {th }}$ of July had a peak discharge of $163 \mathrm{~mm}^{3} / \mathrm{sec}$ while that of $7^{\text {th }}$ August 2012 was $143 \mathrm{~mm}^{3} / \mathrm{sec}$, which was also replicated for 2035(see Figure 11).

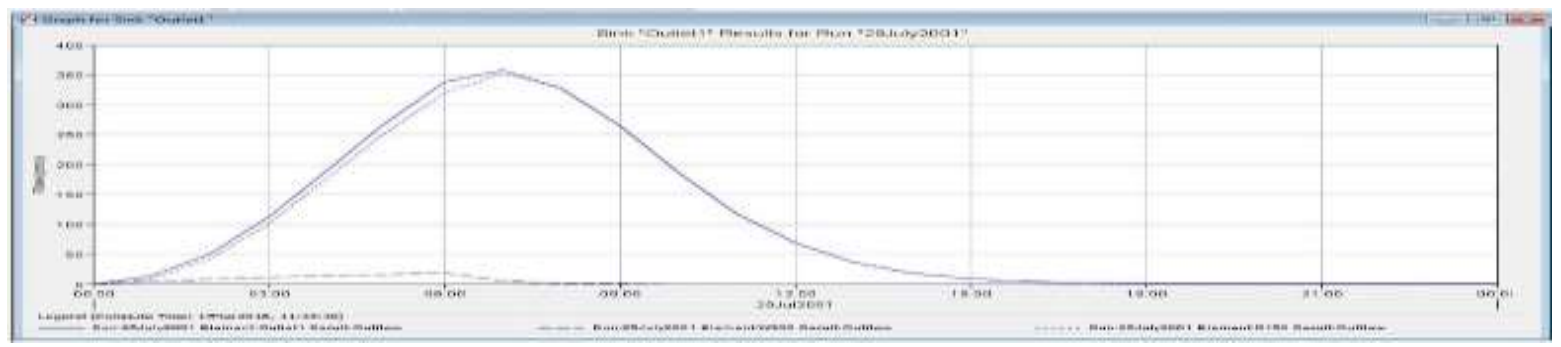

Figure10:Chalawa Total Run-Off 2001

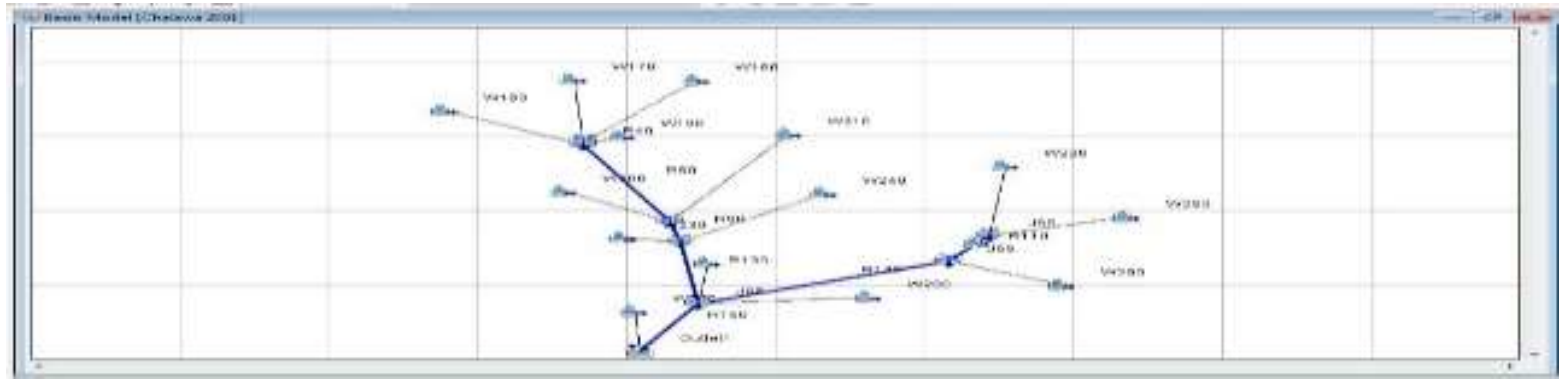

Figure 11: Chalawa Drainage Basin model

Sub-basin W210 has an area of $12.7 \mathrm{~km}^{2}$ and a peak discharge of $93.2 \mathrm{~cm}^{3} / \mathrm{sec}$ and a $25 \mathrm{~mm}^{3}$ depth of runoff with a loss of $5 \mathrm{~mm}^{3}$ within $2 \mathrm{hrs}$ from onset of the rainfall likewise W160 had a peak discharge of $72.2 \mathrm{~cm}^{3} / \mathrm{sec}$ within $3 \mathrm{hrs}$ with an area of $11.9 \mathrm{~km}^{2}$ this basin had a loss of $11 \mathrm{~mm}^{3}$ over a span of $6 \mathrm{hrs}$. The sub-basins with the lowest discharge are W190 and W250 with a peak discharge of 3.1 and $3.7 \mathrm{~cm}^{3} / \mathrm{sec}$ respectively (see Figure 10). Theses sub-basins are also highly urbanized but with small area coverages thus the reason for lower discharge. It was also observed that large sub-basins with extensive impervious surface generated more run-offs and flooding than the smaller basins. This results disputes that of Bhatt (2012) which observed that smaller basins had higher peak discharge than the larger basin, but this agrees with the findings of Ojigi and Shaba (2013) which revealed that larger basins have higher peakdischarge and run-off loss.

Chalawa Run off Discharge Simulation 2012

On the $7^{\text {th }}$ of August 2012 the basin observed a rainfall event with a peak discharge of $143 \mathrm{~mm}^{3}$ which is less than that of 2001. The increase in discharge was mostly observed in areas that had changes in land use and land cover. Sub- basin W160, W200, W220, W230, and W280 increased in the amount and depth of run-off compared to 2001 with $(80,61,60,11$, and 81$)$ $\mathrm{cm}^{3} / \mathrm{sec}$ respectively. The amount of run-off loss also increased as a result of change in LULC (see figure 4), W160, W220,W200 and W210 had losses of $0.1 \mathrm{~mm}^{3}$ within the first $2 \mathrm{hrs}$ rainfall event before reaching field capacity. A similar result was observed by Bandaragoda (2008) in a study on prediction of run-off of ungauged basins. 


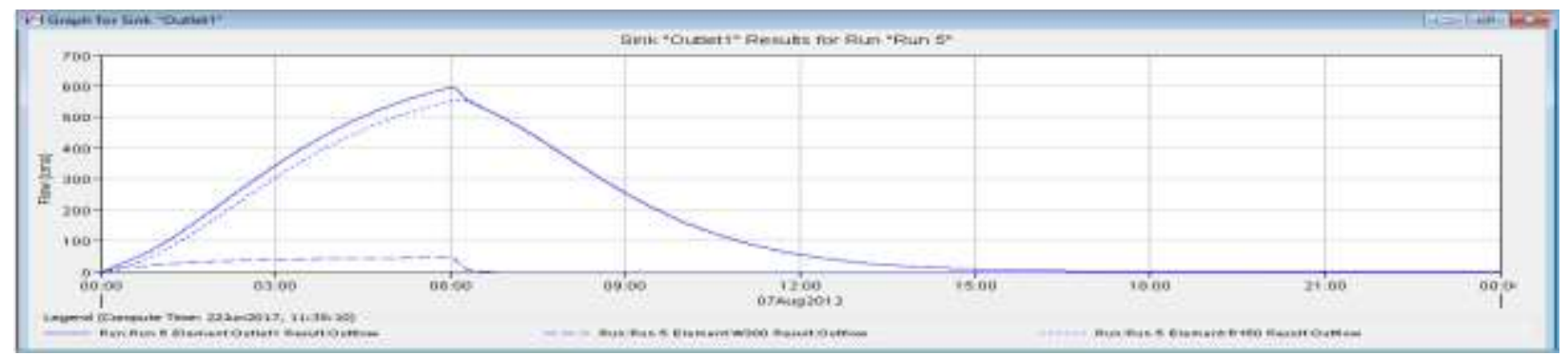

Figure 12: Chalawa Basin Total Run-Off 2012

The findings coincide with that of Alghamand et.al (2010) where changes in land use land cover increased the peak discharge of run- off. Generally, the outlet of the basin discharged $600 \mathrm{~cm}^{3} / \mathrm{sec}$ (see Figure 12) which is much higher than that of 2001 even though with less rainfall amount $\left(143 \mathrm{~cm}^{3}\right)$ indicates a $47 \%$ increase in run-off and thus more flood waters.

\section{Chalawa Run off Discharge Simulation 2035 Forecast}

The Chalawa basin shows a slight decline in peak discharge of the outlet in 2035 (from 600 to $539.7 \mathrm{~cm}^{3} / \mathrm{sec}$ ) (see Figure 13) due to considerations of the ongoing canalization of the kwarin
Gogaw, Kwanar Madobi and Sabuwar Gandu. This is believed to reduce the amount of discharge within the basin and channel it to a more accommodating stream. The increase in peak discharge was observed in sub-basin W220 and W200 $\left(72 \mathrm{~cm}^{3} / \mathrm{sec}\right.$ and $\left.64 \mathrm{~cm}^{3} / \mathrm{sec}\right)$ which were much lower in 2012 . This is in harmony with the findings of Smith (2012) where canalization of the Wanalta Creek County reduced the run-off discharge. It was also revealed in the study of Johnson (1997) that changes in the infiltration rate through paving increases the run-off proportionally to the amount of paving. Sub-basins W 270, W240, W190, W180, W170, and W160 had no run-off loss which indicates an almost $98 \%$ accumulation of run-off.

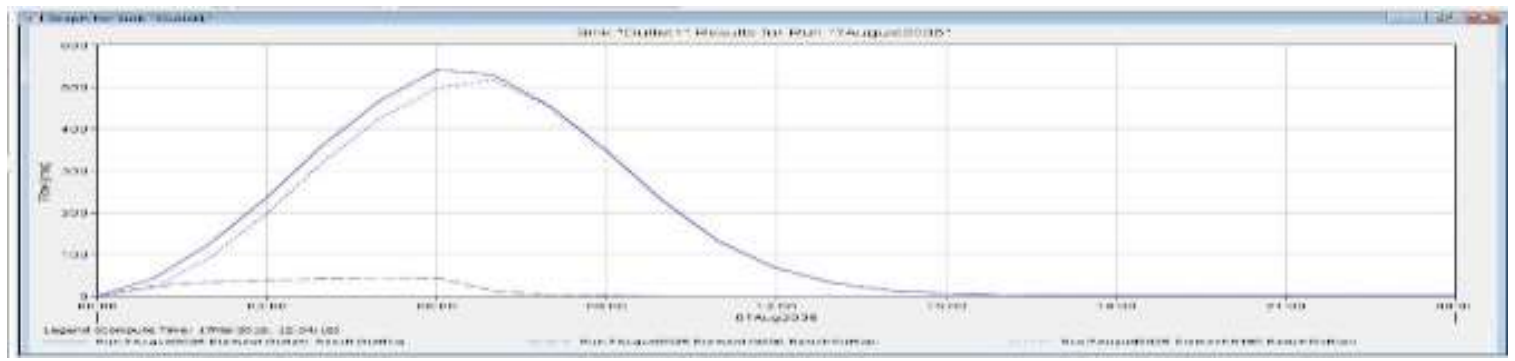

Figure 13: Chalawa Basin Total Run-Off 2035 projection

\section{CONCLUSION}

Generally, Change in land use and land cover have had a significant impact on the amount of run-off especially in the Chalawa basin in 2012 and the Jakara basin in 2035. The research revealed that a change in the landscape with impervious surfaces increased the amount of run-off and reduced the time to peak discharge thereby increasing flood occurrences. Therefore LULC have tremendous effect on flooding in the study area. The study recommended adherence to the city masterplan and construction of canals within each sub-basin for proper conveyance of run- off discharge.

\section{REFERENCES}

Action Aid International, (2006). Climate change, urban flooding and the rights of the urban poor in Africa: Key findings Bhatt, G. (20012). A distribution Hydrologic Modelling System from six African cities. A Report by AAI, October, 2006. Pp. 1-7 Framework for Discovery and Management of Water

Alaghmand, S. Abdullah, R. Abustan, I. and Vosoogh, B. (2010). school. Pennsylvania state university. Chu,L., (2009). GIS-based River Flood Hazard Mapping in Urban Area (A Case PopulationEstimationMethodsinGISandRemoteSensing:ARevi Study in Kayu Ara River Basin, Malaysia. International Journal ew.GIScience\& RemoteSensing,43(3), pp.80-96. of Engineering and Technology. 2(6) 488-500.

Balogun, I. A., Adeyewa, D. Z. Balogun, A. A. and Morakinyo, T. E. (2011). Analysis of urban expansion and land use changes in Akure, Nigeria, using remote sensing and geographic resources. A Ph.D dissertation submitted to the graduate

information system (GIS) techniques. Journal of Geography and Regional Planning. 4(9), pp. 533-541. ISSN 2070-1845 (C)2011 Academic Journals

Bandaragoda, C. (2008). Distributed Hydrological Modelling for Stream Flow Prediction at Unguaged basins. A P.hD dissertation submitted to the facuty of civil engineering. Utah state university. Logon, UT. and Analysis Using GIS \& RS Technologies: Geographic Information for Planning. 2nd FIG Regional Conference Marrakech. Morocco, December 2-5.

Cummings, C. A., Todhunter, P. E., Rundquist, B. C., (2012) Using the Hazus-MH flood model to evaluate community relocation as a flood mitigation response to terminal lake flooding: The case of Minnewaukan, North Dakota, USA
Belaid, M. A. (2003). Urban-Rural Land Use Change Detection 
Journal of Applied Geography Vol. 32 Pp. 889-895

Ejao, S. P. and Abdullahi, U. (2013). Spatiotemporal Analyses of Land Use and Land Cover Changes in Suleja Local Government Area, Niger State, Nigeria.Journal of Environment and Earth Science. Vol. 3, No.9, 2013

García-Pintado, J., Neal, J. C. , Mason, D. C., Dance, S. L., Bates P. D. (2013) Scheduling satellite-based SAR acquisition for sequential assimilation of water level observations into flood modeling. Journal of Hydrology Vol.495 Pp. 252-266.

Gupta, S.K. (2002). Monitoring of change in landuse/landcoever using multi-sensor satellite data. National Institute of technology Allahabad India.

HEC-HMS. (2006). HEC-HMS User's Manual - Hydrologic Annual Workshop/Conference held at Regional Centre for Engineering Center - Army.mil. United States of America. Training in Aerospace Surveys (RECTAS). Pp. 291-303

Retrieved from www.hec.usace.army.mil/software/hec-

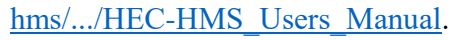

Hemandez, S.L., (1998).GIScience: Disasters andEmergency Management.TransactionsinGIS, 3(2), pp.439-445.

Isham, Z. S. (2014) Urban Flash Flood Risk Assessment and inundation Model Utilizing GIS for Terre Haute, Indiana. An M.Sc. Thesis presented to the college of Graduate and Professional Studies, Department of Earth and Environmental Systems, Indiana State University, Terre Haute, Indiana.

Ishaya, S., Ifatimehin, O. O. and Abaje I. B. (2009), Mapping Flood Vulnerable Areas In A Developing Urban Centre Of Nigeria Journal of Sustainable Development in Africa (Volume 11, No.4, 2009) 1520-5509.

Isma'il, M., Salisu, A., Yusuf, S. and Muhammed, Z. D. (2010). Spatial Analysis of Urban Growth in Kazaure Local Government Area of Jigawa State, Nigeria. International Journal of Geomatics and Geosciences. Vol. 4, No 1, pp 47-60. Jeb, D N. (2013). Flood Risk Analysis in Kaduna Metropolis, Kaduna State Nigeria, Using Geoinformation Science. Predictions in Uguaged Basins. A. Ph.D. dissertation submitted (Unpublished Ph.D. Thesis), Geography Department, Ahmadu to graduate school. Montana state university Bozeman. Bello University, Zaria.

Johnson, R. (1997). Continuous Hydrological Modelling in a large watershed in eastern Canada.A theisis submitted to the faculty of engineering, Technical University Nova-Scotia.

Masher, A.,and Malthus,P., (2013). ComparingtheConsistency of 7758-7762.

ExpertLandCoverKnowledge.InternationalJournalof

GeographicalInformation Science.18(7).189-201.

Mishra, V., Dominguez, F., Lettenmaier, D.P., (2012). Urban precipitation extremes: How reliable are regional climate models? Geophys. Res. Lett. 39.
MunichRe, (2005). Megacities-Mega Risks: Trends and Challenges for Insurances and Risk Management. Retrieved from http://www.munichre.com/publications/302-04271.

Ogba, C, Okon, I and Idoko, M. (2009) Application of Geographic Information System (GIS) towards Flood Management in Calabar, Nigeria Surveyors Key Role in Accelerated Development FIG Working Week 2009 Eilat, Israel, 3-8 May 2009.

Ojigi, M. L. and Shaba, A. H., (2013). Integration of Synthetic Determining Flood Water Threshold in Sokoto and Environs, Nigeria. Proceedings of the Geoinformation Society of Nigeria (GEOSON) \& Nigerian Cartographic Association (NCA) Joint Sajid, X., (2009). Remote Sensing and GIS-based Flood Vulnerability Assessment in Jiangxi Province in China. International Workshop on Geoscience and Remote Sensing. 21 22 Dec. 2009. IEEE Computer Society Washington. DC. USA pp. 332-335.

Salazer A. (2012). Small Area Estimation: A Review of Methods Based on the Application of Mixed Models. S3RI Southampton Statistical Sciences Research Institute.

Samarasinghea ,S.M.J.S., Nandalalb H.K., Weliwitiyac, D.P., Fowzed, J.S.M. , Hazarikad, M.K., Samarakoon, L. (2010) Application Of Remote Sensing And Gis For Flood Risk Analysis: A Case Study At Kalu- Ganga River, Sri Lanka International Archives of the Photogrammetry, Remote Sensing and Spatial Information Science, Volume XXXVIII, Part 8, Kyoto Japan

Montana.

Sreenivasulu, V. and Bhaskar, P. U. (2010). Change Detection in Landuse and landcover using Remote Sensing and GIS Techniques. International Journal of Engineering Science and Technology. Kakinada, A.P, India-533003 Vol. 2(12), 2010,

Whitehead P.G., Robinson, M. (1993) Experimental Basin Studies- an international and historical perspective of forest impacts. Journal of Hydrology. 3(14). 200-214 Aperture Radar (SAR) Imagery and Digital Terrain Model for Methodology Working Paper M03/16. Southampton, UK: use, distribution, and reproduction in any medium, provided the original work is cited appropriately. 